\title{
Post-ruminal or intravenous infusions of carbohydrates or amino acids to dairy cows 1 . Early lactation
}

\author{
I. Schei ${ }^{1,2}$, A. Danfær ${ }^{3}$, I. A. Boman ${ }^{1}$ and H. Volden ${ }^{1 \dagger}$ \\ ${ }^{1}$ Department of Animal and Aquacultural Sciences, Norwegian University of Life Sciences, PO Box 5003, N-1432Ås, Norway; ${ }^{2}$ TINE BA, PO Box 58, N-1430Ås, \\ Norway; ${ }^{3}$ Danish Institute of Agricultural Sciences, Research Centre Foulum, PO Box 50, DK-8830 Tjele, Denmark
}

(Received 11 March 2006; Accepted 11 December 2006)

The objectives of this study were to compare the effects of post-ruminal and intravenous infusions of wheat starch or glucose $(\mathrm{CHO})$ or a mixture of amino acids $(A A)$ on milk protein yield, nitrogen utilisation, plasma metabolites and mammary extraction rate of dairy cows in early lactation. Eight cow, ruminally fistulated, was assigned to two $4 \times 4$ Latin squares during 14-day periods, where the last 7 days were for infusions. Infusions were: (1) starch in the abomasum (SP), (2) glucose in the blood (GB), (3) $A A$ in the abomasum (AP), and (4) $A A$ in the blood ( $A B$ ). The experiment started $54 \pm 4$ days (mean \pm s.E.) post partum (milk yield $33.4 \pm 1.7 \mathrm{~kg}$ ). Daily amounts of nutrients infused were $378,365,341$, and $333 \mathrm{~g}$ for $S P, G B, A P$ and $A B$, respectively. The cows were fed a basal diet consisting of a concentrate mixture and grass silage (55:45 on dry-matter (DM) basis), and DM intake was $17.2 \mathrm{~kg} /$ day. Milk production was affected by site of infusion within substrate, whereas infusion substrates within infusion site (CHO or $A A)$ were of minor importance. Compared with SP infusion, GB infusion increased $(\mathrm{P}<0.05)$ milk protein yield and concentration by $55 \mathrm{~g}$ and $1 \mathrm{~g} / \mathrm{kg}$. The $A B$ infusion tended to $(P<0.10)$ increase milk yield and $E C M$ and increased $(P<0.05)$ protein yield and concentration by 1.8 and $2.2 \mathrm{~kg}, 83 \mathrm{~g}$ and $1.1 \mathrm{~g} / \mathrm{kg}$ compared with AP infusion, respectively. Nitrogen balance data indicated higher losses of metabolic faecal nitrogen (MFN) by abomasal than by intravenous infusions, and an increased $(P<0.05)$ catabolism for $A P$ and $A B$ infusions compared with $S P$ and $G B$ infusions. $G B$ infusion did not increase $(P>0.10)$ plasma glucose or insulin concentrations above that of SP infusion. Compared with the SP infusion, the GB infusion had minor effect on plasma $A A$. AP infusion increased $(P<0.05)$ plasma non-essential $A A(N E A A)$ concentration compared with $A B$ infusion, whereas infusion site of $A A$ had no effect $(P>0.05)$ on essential $A A(E A A)$ or branched-chain $A A(B C A A)$. Although a higher milk protein synthesis was observed for $A B$ infusion, the mammary extraction rate was not higher $(P>0.05)$ than for $A P$ infusion. Across infusion site, $A P$ and $A B$ infusions increased plasma concentration of $E A A$ and $B C A A$, but compared with $G B$ infusion, the mammary extraction rates tended $(\mathrm{P}<0.10)$ to be lower. It is concluded that abomasal nutrient infusion increases loss of MFN and that the gastrointestinal metabolism influences the nutrients available for milk synthesis. Our conclusion is that when glucose was infused, AA limited a further milk protein synthesis, but when AA was infused, glucose or energy substrate might have been the limiting factor. Our results verify that glucogenic substrates are limiting when cows are in negative energy balance.

Keywords: amino acid infusion, dairy cows, early lactation, glucose

\section{Introduction}

Milk protein response to dietary supplementation has been addressed in numerous reviews (DePeters and Cant, 1992; Chamberlain and Yeo, 2003). The response depends on a number of factors, including stage of lactation, genetic capacity, basal protein and energy status, amount of amino acid (AA) and energy substrates supplied as well as their interactions. Production and infusion experiments that have

\footnotetext{
${ }^{\dagger}$ E-mail: harald.volden@umb.no
}

evaluated these factors have shown variable success in affecting both milk protein production and content. The low and variable response of metabolisable protein supply on milk protein production (Aikman et al., 2002; Raggio et al., 2004; Schei et al., 2005) may be due to the fact that some AA are utilised as an energy source, some AA are used as a glucogenic precursors and also, increased $A A$ supplementation may affect hormones regulating lactogenic metabolism (Reynolds et al., 1994). Further improvement in prediction of dietary effects on milk protein production requires a better understanding of factors 
affecting intermediary metabolism of glucogenic substrates and AA. Lately, attention has been given to the gastrointestinal tissues and the liver metabolism. Their high rate of protein turn-over and other energetically expensive processes may affect the nutrient supply to the mammary gland (Reynolds, 2002). This might imply that AA that could be available for milk protein synthesis is used as energy substrate in the gastro-intestinal tract or in other tissues. Thivierge et al. (2002) discussed this by comparing separate experiments of intravenous and abomasal AA infusions and concluded that milk protein yield would be higher with intravenous than with abomasal infusion. However, in their own study when comparing abomasal and jugular AA infusion, only small differences in milk yield and protein responses were observed in cows on restricted feed intake and low protein diets (Thivierge et al., 2002). They concluded that the size of the effect of the gastrointestinal and liver energy and protein turn-over on nutrient delivery to the mammary gland was still not clear. In a similar study, Aikman et al. (2002) found no effect of mesenteric compared with abomasal AA infusion on milk protein response. Therefore, our hypothesis is that compared with intravenous AA infusion, increased intestinal AA supply will only marginally increase the milk protein production and increase the urine nitrogen $(\mathrm{N})$ excretion due to an increased metabolism of these AA in the intestine or the liver.

It has been suggested that increased intestinal starch digestion may enhance milk protein production by sparing AA from being used in the gut and liver (Nocek and Tamminga, 1991). Post-ruminal infusion studies have shown that increased starch supply reduces urinary $\mathrm{N}$ excretion and increase $\mathrm{N}$ body retention (Volden and Harstad, 2002). Small intestinal starch digestion may also provide glucose for absorption and can increase the glucose supply to the mammary gland directly and therefore reduce liver gluconeogenesis. However, it may also allow greater glucose oxidation by peripheral tissues (Reynolds et al., 2001) and thus reduce glucose delivery to the mammary gland. The effects of intestinal glucose or starch supply on milk protein synthesis have proved to be highly variable (Hurtaud et al., 1998 and 2000; Reynolds et al., 2001) and our understanding of the fate of glucose liberated during starch digestion in the small intestine is rather limiting. As far as we are aware, no direct comparison of post-ruminal starch and intravenous glucose infusions has been done and our hypothesis is that intravenous glucose supplementation will give similar milk protein response as increased intestinal starch supply. Therefore, we want to compare directly, within the same animals, the effect of abomasal starch or intravenous glucose delivery on mammary glucose supply. Moreover, we also hypothesise that when infusing an abomasal AA mixture versus starch the essential AA (EAA) supply to the mammary gland will be higher and thus improve the milk protein production. Cows in negative energy balance have a high need for glucose because they mobilise fat as energy and have limited body reserves of glucogenic compounds. A combination of low energy supply and high metabolisable protein supply has shown to stimulate milk production (Ørskov et al., 1981; Schei et al., 2005). However, it is not clear if this response is solely explained by increased AA supply or that part of the AA has been used as source for glucose and thus improved glucogenic status of the animal. Therefore, the present study was designed to use cows in negative energy balance.

With this background we have performed an experiment where we wanted to evaluate multiple comparisons of starch, glucose or AA infused in the abomasum or intravenously on production responses, $\mathrm{N}$ utilisation and plasma metabolites in early lactation. The objectives were to compare the effects of (1) abomasal starch versus intravenous glucose infusion, (2) abomasal versus intravenous AA infusion, (3) abomasal starch versus AA infusion, (4) intravenous glucose versus amino acid infusion.

\section{Material and methods}

\section{Animals and basal diets}

Eight Norwegian Red cows were fitted with ruminal cannulae on average 49 days before expected calving date. The cows were from two different genetic groups and were in their second or third (two cows) lactation. The experiment was conducted in early lactation, starting $54 \pm 4$ (mean \pm S.E.) days post partum with a mean daily milk yield of $33.4 \pm 1.7 \mathrm{~kg}$. Cows were housed in individual tie stalls and milked twice daily at 0630 and $1530 \mathrm{~h}$. Cows were fed a basal ration consisting of concentrate and grass silage in the ratio 55:45 on dry matter (DM) basis and at a fixed rate of $95 \%$ of net energy lactation (NEL) requirements (Ekern, 1991) based on 10-day milk yields prior to the start of the experiment to ensure constant DM intake (DMI). The concentrate mixture consisted mainly of barley and oats (Table 1) and was formulated to have low metabolisable protein content (Table 2). The grass silage was first cut and pre-wilted; it consisted of a mixture of timothy, meadow fescue and red clover, ensiled with a formic acid based additive ('GrasAAT', Hydro Agri, Oslo, Norway). Silage was stored in tower silos until trial start, then packed in plastic bags and frozen until use. The concentrate mixture was fed from parturition, and silage was fed from 2 weeks before

Table 1 Ingredients of the concentrate mixture $(\mathrm{g} / \mathrm{kg})$ used in the basal diet

\begin{tabular}{lr}
\hline \hline Ingredient & $\mathrm{g} / \mathrm{kg}$ \\
\hline Barley & 564 \\
Oats & 200 \\
Soya-bean meal & 120 \\
Molasses & 50 \\
Rapeseed & 30 \\
Limestone powder & 14 \\
Vitamins and minerals & 22 \\
\hline \hline
\end{tabular}


Table 2 Chemical composition ( $g / k g$ dry matter (DM)), protein values $(\mathrm{g} / \mathrm{kg} \mathrm{DM})$, and energy values (MJ/kg DM) of the concentrate mixture and the grass silage

\begin{tabular}{lcc}
\hline \hline & Concentrate & Silage \\
\hline Dry matter $(\mathrm{g} / \mathrm{kg})$ & 883 & 228 \\
Crude protein & 170 & 141 \\
Neutral-detergent fibre & 204 & 602 \\
Crude fat & 46 & 42 \\
Starch & 440 & - \\
Ash & 71 & 63 \\
RDP $^{\dagger}$ & 88 & - \\
RUP $^{\ddagger}$ & 82 & - \\
AAT $^{\S}$ & 105 & 69 \\
NEL $^{\text {ๆ }}$ & 7.97 & 5.73 \\
\hline \hline
\end{tabular}

${ }^{\dagger}$ Rumen degradable protein, calculated at a ruminal outflow rate of $8 \%$ per $h$.

${ }^{\ddagger}$ Rumen undegradable protein, calculated at a ruminal outflow rate of $8 \%$ per $h$.

Amino acids absorbed in the small intestine.

'Net energy lactation (Van Es, 1975 and 1978; Ekern, 1991).

experimental start. One week before the first infusion period, DM feed allowance was reduced to the experimental level. Feed was offered manually three times daily, at 0600,1400 and $2200 \mathrm{~h}$ at equal amounts for the first two offers, but for practical reasons the amount was reduced to half at $2200 \mathrm{~h}$. Feed refusals were removed daily before morning feeding and recorded. Cows had free access to water and trace mineralised salt blocks.

\section{Experimental procedures and treatments}

Two restrictedly run $4 \times 4$ Latin squares were designed. Periods of 14 days were used, where days 1 to 7 served as an adaptation and resting period, and days 8 to 14 were for infusions. Measurements and sample collections were performed from days 12 to 14 . The restriction of the design was to avoid two consecutively intravenous treatments on the same animal. Infusions were done in four cows simultaneously. The cows within square were randomly allocated to the first infusion treatment. When the first four cows ended an infusion period and went over to the resting period of 7 days, the other four cows started the infusion period. The treatments were two isoenergetic substrates of starch and glucose and two equal AA mixtures infused into the abomasum or jugular vein. The AA infusion levels were chosen to provide similar metabolisable energy (ME) as the carbohydrate $(\mathrm{CHO})$ infusions. Treatments were: (1) starch in the abomasum (SP), (2) glucose in the blood (GB), (3) $A A$ in the abomasum (AP), and (4) AA in the blood (AB). Pure wheat starch (Tritici amylum) and glucosum anhydricum from Norsk Medisinaldepot (Oslo, Norway) were used as starch and glucose supplements. Starch, and not glucose, was infused in the abomasum to simulate a more real feeding since glucose available for absorption enters the intestine as starch. Hydrolysed wheat starch was used because it has close to $100 \%$ digestibility in the small intestine. The AA mixture contained $16 \mathrm{~L}$-amino acids from
AppliChem (Darmstadt, Germany) and Sigma Chemical (aspargine only; St Louis, MO) with an overall composition similar to the AA profile in duodenal digesta on a grass silage-based diet (Volden, 1999; Table 3). Daily infusion of starch, glucose and AA were 400,446 and $400 \mathrm{~g}$, respectively, corresponding to $23 \mathrm{~g}$ of infusion per $\mathrm{kg}$ DMl. The daily substrate infusion was equivalent to 4.68 and 4.01 MJ ME for starch/glucose and AA, respectively (Boisen and Verstegen, 2000). ME values of starch/glucose and AA were 3.51 and $3.01 \mathrm{MJ}$, respectively. The abomasal infusions of starch and AA were dissolved in 16 and $12 \mathrm{I}$ of tap water, respectively. Starch portions were bulked in a 100-I tank with a mixer for continuous stirring to avoid sedimentation. The AA infused into the abomasum was dissolved in temperate tap $\left(35^{\circ} \mathrm{C}\right)$ water to avoid precipitations. Daily solutions of starch and AA were infused using the same peristaltic pump with an infusion rate of 11.1 and $8.3 \mathrm{ml} / \mathrm{min}$, respectively. Total daily volumes of glucose and AA infusions in the jugular vein were $8 \mathrm{I}$, which provided an infusion rate of $5.6 \mathrm{ml} / \mathrm{min}$. Intravenous glucose and AA solutions were sterilised before use. The following procedures were performed: Batches of seven daily portions of glucose and AA were dissolved in 14 and $35 \mathrm{I}$ of pyrogen-free sterile water, respectively. The solutions were filtered through a vacuum filter, $0.2 \mu \mathrm{m}$ pore size (Pall Norge AS, Hønefoss), into sterile bottles of concentrated daily portions of 2 and $5 \mathrm{I}$ and then frozen at $-18^{\circ} \mathrm{C}$ until use. Before use, the solutions were thawed and dissolved to $8 \mathrm{I}$ in ultra-purified sterile pyrogen-free water with temperature of about $40^{\circ} \mathrm{C}$ and $\mathrm{pH}$ in the $\mathrm{AA}$ solution was adjusted to 7.4 using $\mathrm{HCl}$. Abomasal infusions were done with a tube inserted through the rumen

Table 3 Amino acid (AA) profile (\% of $A A$ ) and daily amounts (g/day) of $A A$ infused

\begin{tabular}{|c|c|c|}
\hline & \multicolumn{2}{|c|}{ AA } \\
\hline & Profile & g/day \\
\hline Ala & 6.3 & 25.6 \\
\hline Arg & 5.2 & 20.9 \\
\hline $\mathrm{Asp}^{\dagger}$ & 11.0 & 44.7 \\
\hline Cys & 1.6 & 6.5 \\
\hline Glu & 13.9 & 56.2 \\
\hline Gly & 9.2 & 37.3 \\
\hline His & 2.3 & 9.2 \\
\hline lle & 5.5 & 22.3 \\
\hline Leu & 8.1 & 33.0 \\
\hline Lys $^{\ddagger}$ & 9.1 & 37.0 \\
\hline Met & 2.1 & 8.4 \\
\hline Phe & 4.8 & 19.4 \\
\hline Pro & 4.4 & 17.9 \\
\hline Ser & 5.1 & 20.7 \\
\hline Thr & 5.1 & 20.6 \\
\hline Val & 6.2 & 25.2 \\
\hline Total & 100.0 & 404.9 \\
\hline
\end{tabular}


cannulae and the reticulo-omasal orifice. Prior to the experiment, cobalt EDTA was infused for 5 days to check the possibility of ruminal backflux of solutions, but no increase in cobalt was observed in the rumen. The equipment was checked twice daily to ensure correct placement in the abomasum. The blood infusions were done through the jugular vein, and the tubing was inserted under local anesthesia of $1 \mathrm{ml}$ Lidocain (Adrenalin $5 \mu \mathrm{g} / \mathrm{ml})$.

\section{Measurements and sample collections}

Milk yields were recorded daily and milk samples were taken at each milking. Daily milk samples were bulked in proportion to total volume, and bronopol (2-bromo-2-nitropropan-1,3-diol) was added as a preservative. The samples were stored at 2 to $4^{\circ} \mathrm{C}$ until analysed for fat, protein and lactose. Milk yields and chemical composition for days 4 to 6 were used as an adaptation period to infusion and 11 to 13 were used to compare effects of infusions. Silage samples were collected at the time the silage was packed in plastic bags and stored frozen. Two composite samples of the silage and one composite sample of the concentrate mixture were analysed for chemical composition. To measure total tract organic matter (OM) digestibility and $\mathrm{N}$ balance, total faeces and urine were collected separately for three consecutive days, starting on day 11. From daily amounts of faeces and urine, $10 \%$ was stored at $-20^{\circ} \mathrm{C}$. After finishing each collection period, the 3 days' samples within cow were mixed and $10 \%$ of the combined samples were stored frozen $\left(-20^{\circ} \mathrm{C}\right)$ until analyses. Sulphuric acid was added to urine samples when necessary to keep $\mathrm{pH}$ below 4 . Blood samples from the jugular vein, mammary vein and coccygeal vein (10 $\mathrm{ml}$ in EDTA tubes) were drawn on days 7 and 14 in each period at 0500, 0800 and $1200 \mathrm{~h}$. For those cows having intravenous infusions, blood samples were taken from the opposite jugular vein of the infusion site. Jugular blood was used for plasma urea and hormone analyses, and blood from the tail vein was used for determination of other plasma metabolites. Blood from the tail vein is considered to represent arterial blood as metabolism in the tail is assumed to be insignificant in relation to whole body metabolism (Vanhatalo et al., 2003b). Samples were immediately put on ice and then centrifuged at $500 \mathrm{~g}$ for $20 \mathrm{~min}$. Plasma was stored at $-80^{\circ} \mathrm{C}$ until analysis of glucose, non-esterified fatty acids (NEFA), urea, free AA and hormones (insulin, glucagon, IGF-1, GH). For AA analysis, plasma samples were pooled over the daily sampling times to provide one sample per cow. Body temperature was taken twice daily to reveal possible infections at an early stage; no antibiotic was added to the intravenous infusion solutions.

\section{Analytical procedures}

Samples of silage and faeces were freeze-dried and ground through a $1.0-\mathrm{mm}$ screen prior to analyses. Content of DM, ash and Kjeldahl-nitrogen ( $\mathrm{N}$ ) in feeds, faeces and urine ( $\mathrm{N}$ only) were determined according to Association of Official Analytical Chemists (1980). Nitrogen in faeces and urine were analysed in fresh samples. Feeds and faeces were analysed for neutral-detergent fibre (NDF) (Van Soest et al., 1991), crude fat (Volden et al., 1999) and starch (McCleary et al., 1994). NEL in the silage was measured by Infralyser 500 (Bran Luebbe, Germany) calibrated on sheep in vivo digestibility data, and NEL and amino acids absorbed in the small intestine (AAT) in the concentrate and silage (AAT only) was calculated from tabulated values after methods developed by Van Es (1975 and 1978), Ekern (1991) and Madsen et al. (1995). Nucleic acid bases (NAB) in faeces were determined using HPLC as described by Volden et al. (1999). However, in accordance with the findings of Makkar and Becker (1999), the method was further modified by reducing the concentration of $\mathrm{HClO}_{4}$ to $2 \mathrm{~mol} / \mathrm{l}$, lowering the hydrolysis temperature to $95^{\circ} \mathrm{C}$, and removal of excess $\mathrm{HClO}_{4}$ by precipitation with $\mathrm{KOH}$. Allopurinol was used as internal standard. The sum of all nucleic acid bases (adenine, cytosine, guanine, thymine and uracil) was used in the calculation of the microbial $\mathrm{N}$ in faeces. Individual milk samples were analysed for fat, protein and lactose with an infrared milk analyser (MilkoScan, Foss Electric, Hillerød, Denmark). Energy-corrected milk (ECM) and $\mathrm{N}$ in milk were calculated from chemical composition according to the method of Sjaunja et al. (1990). Plasma NEFA, urea and glucose were analysed on Cobas Mira S spectrophotometer (F. Hoffmann - La Roche $\&$ Co, Switzerland). Plasma urea was analysed using enzymatic urease/GLDH, kit no. 070385 6, NEFA was measured by enzymatic colorimetric procedure (kit no 994-75 409), and glucose by using hexokinase/kit no A11A 0116 . For glucagon analysis, $1 \mathrm{ml}$ plasma was added $70 \mu \mathrm{l}$ bovine aprotinin (Sigma-Aldrich, Norway) as a preservative. Glucagon was analysed by a radio-immunoassay using a double antibody glucagon procedure (DPC, Los Angeles, USA). Non-competitive time-resolved immunofluorometric assays (TR-IFMA) of the sandwich type was used to determine insulin, BGH and IGF-1 as previously described by Løvendahl and Purup (2002), Løvendahl et al. (2003) and Frystyk et al. (1995), respectively. The content of AA in milk and free $A A$ in plasma were analysed by ion exchange chromatography using a Biochrom 20 amino acid analyser (Biochrom Ltd, Cambridge, UK). Separation of total AA was achieved on a sodium high-performance column using sodium-based eluents (Oxidised Hydrolysate Chemical Kit, Biochem Ltd), whereas separation of free AA was achieved on a lithium high-performance column using lithium-based effluents (Physiological Fluid Chemical Kit, Biochrom Ltd). Peak detection was performed with UV absorbance at $440 \mathrm{~nm}$ and $570 \mathrm{~nm}$ after post-column derivatisation with ninhydrin. Data were analysed against appropriate external standards (Sigma Chemical, St Louis, Mo., USA) using the Chromeleon ${ }^{\circledR} \quad$ Chromatography Management Software (Dionex Ltd, Surrey, UK). The milk samples were oxidised with a performic acid/phenol mixture, hydrolysed with $6 \mathrm{~mol} / / \mathrm{HCl}$ for $23 \mathrm{~h}, \mathrm{pH}$ adjusted to 2.200 , diluted with a $0.2 \mathrm{~mol} / \mathrm{l}$ sodium citrate loading buffer, $\mathrm{pH} 2.2$ (Biochrom Ltd) and micro-filtrated (0.2 $\mu \mathrm{m}$ Spartan membrane filter, 
Schleicher \& Schuell, Dassel, Germany) prior to injection $(40 \mu \mathrm{l})$. Norleucine was used as an internal standard. Plasma $(300 \mu \mathrm{l})$ was deproteinised by mixing with $30 \mu \mathrm{l}$ of $35 \%$ sulphosalicylic acid. The mixture was incubated at $4^{\circ} \mathrm{C}$ for $30 \mathrm{~min}$ and centrifuged at $16000 \mathrm{~g}$ for $15 \mathrm{~min}$ (Biofuge Fresco, Heraeus Instruments, Kendro Laboratory Products $\mathrm{GmbH}$, Hanau, Germany). Of the supernatants, $200 \mu \mathrm{l}$ were diluted with $200 \mu \mathrm{l} 0.2 \mathrm{~mol} / \mathrm{l}$ lithium citrate loading buffer, pH 2.2 (Biochrom Ltd) and micro-filtrated (0.2 $\mu \mathrm{m}$ Spartan membrane filter, Schleicher \& Schuell) prior to injection $(30 \mu \mathrm{l})$. S-2-aminoethyl-1-cysteine was used as an internal standard. The samples were analysed immediately or stored in a refrigerator $\left(4^{\circ} \mathrm{C}\right)$ for a maximum of 3 days.

\section{Animal care}

All cows were cared for according to laws and regulations controlling experiments in live animals in Norway (i.e. the Animal Protection Act of 20 December, 1974, and the Animal Protection Ordinance Concerning Experiments in Animals of 15 January, 1996).

\section{Calculations and statistical analysis}

Intake of ME was calculated from total tract digestibility of organic matter using the formulas in the Dutch NEL system (Van Es, 1975 and 1978). Infusions of abomasal substrates were added to the intake when calculating the digestibility, ME intakes, and energy balance but infusions are not included when total DMI is presented. Intravenously infused substrates were also added to the calculated ME values. Gross energy value of $15.6 \mathrm{MJ} / \mathrm{kg}$ was used for glucose, and the sum of gross energy values of individual AA in the mixture, calculated to $20.6 \mathrm{MJ} / \mathrm{kg}$, was used for the AA mixture (Boisen and Verstegen, 2000). Animal maintenance requirements were estimated by using individual body weights as described by Van Es (1975). The NEL balance (MJ/day) as a percentage of milk NEL was calculated as: $100 \times[$ (ME intake - ME maintenance) $\times 0.67$ milk NEL]/milk NEL. Energy efficiency was calculated as: $100 \times$ milk NEL/(ME intake - ME maintenance). Nitrogen balance was calculated as $\mathrm{N}$ intake minus $\mathrm{N}$ secretion and excretion in milk, urine and faeces. Mammary extraction of plasma metabolites and AA was calculated as arteriovenous (AV) difference divided by arterial concentration. Data used in the statistical analyses were averages from the last 3 days of each treatment period. The effects of treatment on feed intake, digestibility, milk yield, milk chemical production and composition, and $\mathrm{N}$ balances were run using the following statistical model with the MIXED procedure of Statistical Analysis Systems Institute (1999):

$$
Y_{i j k l}=\mu \alpha_{i}\left(\delta_{k}\right)+\chi_{j}+\delta_{k}+A_{l}\left(\delta_{k}\right)+\chi_{j} \delta_{k}+\varepsilon_{i j k l}
$$

where: $Y_{i j k l}=$ dependent variable; $\mu=$ overall mean; $\alpha_{i}=$ fixed effect of infusion period $i$ within genetic group $k$ $\{i=1, \ldots, 4\} ; \chi_{j}=$ fixed effect of treatment $j\{j=1, \ldots, 4\}$; $\delta_{k}=$ fixed effect of genetic group $k\{k=1,2\} ; A_{/}\left(\delta_{k}\right)=$ random effect of cow $I$ within genetic group $k\{I=1, . ., 4\}$, $A\left(\delta_{l}\right) \sim \mathrm{N}\left(0, \sigma_{A}^{2}\right) ; \chi_{j} \delta_{k}=$ interaction between treatment and genetic group; $\varepsilon_{i j k l}=$ random residual variation, $\epsilon \sim$ $N\left(0, \sigma^{2}\right)$. The experimental variation of period across square was assumed controlled and similar. When data on plasma metabolites and hormones were tested, a fixed effect of sampling time and its interactions with treatment were included in the model. All determinations of glucagon from the first period are missing because of lack of preservatives. The model was tested for residual effects, but no effect was detected, and it was therefore removed from the model. Pearson correlation coefficient based on daily means of individual cow samples from each period was run between plasma urea and urinary $\mathrm{N}$ excretion. All results are presented as least square means with standard error of the mean. Pdiff-statement was used to test multiple comparisons between treatment means. In the adjustments of the differences of LSMeans the ADJUST $=$ TUKEY and DIFF $=$ ALL option was used. Differences were considered statistically significant when $P \leq 0.05$, and trends were considered to exist when $0.05<P \leq 0.10$.

\section{Results}

Feed intake and total tract digestibility

Infusion levels, feed intake and total tract apparent digestibility of $\mathrm{OM}$ and crude protein (CP) are presented in Table 4. The amount of substrates infused was lower than planned and this will affect the calculated nutrient supply. Daily ME intake was not affected by treatments $(P>0.10)$ but as planned, total $C P$ intake was higher in $A P$ and $A B$ infusions than in $\mathrm{SP}$ and $\mathrm{GB}$ infusions, on average $331 \mathrm{~g}$ higher. Treatments did not differ $(P>0.10)$ in OM digestibility, but the digestibility of $\mathrm{CP}$ was 3.8\%-units higher $(P<0.05)$ when starch was infused than when other nutrients were infused. Calculated energy balances showed that the cows were underfed by, on average, $15.1 \mathrm{MJ}$ NEL but no difference $(P<0.05)$ was found between treatments.

\section{Milk yield, composition and efficiency}

Milk yield, milk composition and milk efficiency are presented in Table 5. In general, the production responses were mostly affected by infusion site (abomasal v. blood; measured as individual treatment comparisons), whereas infusion substrates ( $\mathrm{CHO}$ v. $\mathrm{AA}$; measured as individual treatment comparisons) were of minor importance. Compared with the AP infusion, the $A B$ infusion was higher $(P<0.05)$ or tended to $(P<0.10)$ be higher in milk yield, ECM, protein and lactose yields, and protein concentration, with numerical values of 1.8 and $2.2 \mathrm{~kg}, 83$ and $82 \mathrm{~g}$ and $1.1 \mathrm{~g} / \mathrm{kg}$, respectively. The GB infusion had $55 \mathrm{~g}$ and $1 \mathrm{~g} / \mathrm{kg}$ higher $(P<0.05)$ protein yield and protein concentration than the SP infusion. No differences $(P>0.05)$ were found between $G B$ and $A B$ infusions, or between $S P$ and 
Schei, Danfær, Boman and Volden

Table 4 Means of daily intake and digestibility of nutrients by dairy cattle infused with carbohydrates or amino acids into the abomasum or blood in early lactation

\begin{tabular}{|c|c|c|c|c|c|c|}
\hline & \multicolumn{6}{|c|}{ Treatments $^{\dagger}$} \\
\hline & SP & $\mathrm{GB}$ & AP & $A B$ & s.e. & Significance \\
\hline Infusion (g) & $378^{j}$ & $365^{\mathrm{jk}}$ & $341^{\mathrm{kl}}$ & $333^{1}$ & 9.0 & * \\
\hline \multicolumn{7}{|l|}{ Intake (kg dry matter) } \\
\hline Total & 17.1 & 17.3 & 17.0 & 17.3 & 0.39 & \\
\hline Concentrate & 9.6 & 9.6 & 9.6 & 9.6 & - & - \\
\hline Silage & 7.5 & 7.7 & 7.4 & 7.7 & 0.39 & \\
\hline Crude protein $^{\ddagger}$ & $2.723^{\mathrm{k}}$ & $2.734^{\mathrm{k}}$ & $3.037^{j}$ & $3.081^{j}$ & 0.0570 & $* * *$ \\
\hline Starch intake ${ }^{\ddagger}$ & $4.678^{j}$ & $4.290^{k}$ & $4.300^{\mathrm{k}}$ & $4.302^{\mathrm{k}}$ & 0.0085 & $* * *$ \\
\hline Metabolisable energy (MJ) & 170 & 171 & 168 & 172 & 4.3 & \\
\hline Energy balance $^{\S}(\%)$ & -12.4 & -13.2 & -15.8 & -16.1 & 4.68 & \\
\hline \multicolumn{7}{|l|}{ Digestibility } \\
\hline Organic matter (\%) & 68.5 & 68.1 & 68.8 & 67.5 & 0.75 & \\
\hline Crude protein (\%) & $66.5^{\mathrm{k}}$ & $69.4^{\mathrm{j}}$ & $71.2^{\mathrm{j}}$ & $70.2^{\mathrm{j}}$ & 0.95 & * \\
\hline
\end{tabular}

${ }_{j, k, l}$ Means within the same row and lactation stage with different superscripts differ $(P<0.05)$.

${ }^{\dagger} \mathrm{SP}=$ starch infused in abomasum; $\mathrm{GB}=$ glucose infused in blood; $\mathrm{AP}=$ amino acids infused in abomasum; $\mathrm{AB}=$ amino acids infused in blood

${ }^{\ddagger}$ Included infused solutions.

$\S 100 \times[(\mathrm{ME}$ intake $-\mathrm{ME}$ maintenance $) \times 0.67-$ milk NEL $] /$ milk NEL.

AP infusion except in lactose concentration which tended to differ $(P<0.10)$ between treatments.

\section{$N$ balance}

Nitrogen balance data are presented in Table 6. The $\mathrm{N}$ intake was in accordance with dietary CP intake and infusion treatments. A numerical, but not significantly $(P>0.05)$ higher total faecal $N$ loss was observed for SP and $A P$ treatments compared with $G B$ and $A B$ treatments, respectively. In percentage of $N$ intake, the faecal $N$ loss was higher $(P<0.05)$ by the SP infusion than for $G B, A P$ and $A B$ infusions, with respectively values of $3.0,4.8$ and
$7.0 \%$ units. Total faecal $\mathrm{N}$ loss was also $4 \%$ units higher $(P<0.05)$ for $G B$ infusion than for $A B$ infusion. The $A P$ and $A B$ infusions had, on average, $47 \mathrm{~g}(7.2 \%$ units) higher $(P<0.05)$ urinary $N$ excretions than the $\mathrm{SP}$ and $\mathrm{GB}$ infusions. The SP infusion had $0.92 \mathrm{mmol} / \mathrm{l}$ lower $(P<0.05)$ plasma urea than the other treatments. Based on individual cow measurements, a low correlation was found between plasma urea and excretion of total $\mathrm{N}(r=0.33, n=64$, $P<0.05)$ or $N$ concentration $(r=0.27, n=64, P<0.05)$ in the urine. When $\mathrm{N}$ secretion in milk was calculated as a proportion of total $\mathrm{N}$ intake, the GB infusion had the highest and AP the lowest $\mathrm{N}$ output. The sum of $\mathrm{N}$ output in

Table 5 Means of daily milk yield, milk composition and energy efficiency by dairy cattle infused with carbohydrates or amino acids into the abomasum or blood in early lactation

\begin{tabular}{|c|c|c|c|c|c|c|}
\hline & \multicolumn{6}{|c|}{ Treatments $^{\dagger}$} \\
\hline & SP & GB & AP & $A B$ & s.e. & Significance \\
\hline \multicolumn{7}{|l|}{ Yield } \\
\hline Milk (kg) & 30.6 & 31.5 & 30.4 & 32.2 & 1.50 & $\|$ \\
\hline $\mathrm{ECM}^{\ddagger}(\mathrm{kg})$ & 28.4 & 29.7 & 28.3 & 30.5 & 1.53 & $\|$ \\
\hline Protein $(\mathrm{g})$ & $897^{\mathrm{k}}$ & $952^{j}$ & $897^{\mathrm{k}}$ & $980^{j}$ & 39.3 & * \\
\hline Fat $(g)$ & 1096 & 1152 & 1098 & 1192 & 74.6 & \\
\hline Lactose $(\mathrm{g})$ & 1481 & 1515 & 1453 & 1535 & 66.8 & $\|$ \\
\hline \multicolumn{7}{|l|}{ Milk composition $(\mathrm{g} / \mathrm{kg})$} \\
\hline Protein & $29.3^{1}$ & $30.3^{\mathrm{jk}}$ & $29.5^{\mathrm{kl}}$ & $30.6^{\mathrm{j}}$ & 0.50 & * \\
\hline Fat & 35.5 & 36.2 & 36.4 & 36.9 & 1.26 & \\
\hline Lactose & 48.2 & 48.1 & 47.8 & 47.7 & 0.59 & $\|$ \\
\hline Milk energy (MJ) & 88.8 & 92.9 & 88.4 & 95.3 & 4.79 & $\|$ \\
\hline Energy efficiency ${ }^{\S}(\%)$ & 79.4 & 80.2 & 81.0 & 82.5 & 4.31 & \\
\hline
\end{tabular}

j,k,l Means within the same row and lactation stage with different superscripts differ $(P<0.05)$.

${ }^{\dagger} \mathrm{SP}=$ starch infused in abomasum; $\mathrm{GB}=$ glucose infused in blood; $\mathrm{AP}=$ amino acids infused in abomasum; $\mathrm{AB}=$ amino acids infused in blood.

${ }^{\ddagger}$ Energy corrected milk.

$\S 100 \times$ milk energy/(ME intake - ME maintenance).

"Approaching significance $(P<0.10)$. 
Table 6 Means of daily nitrogen $(N)$ intake and utilisation, plasma urea and faecal nucleic acid bases by dairy cattle infused with carbohydrates or amino acids into the abomasum or blood in early lactation

\begin{tabular}{|c|c|c|c|c|c|c|}
\hline & \multicolumn{6}{|c|}{ Treatments $^{\dagger}$} \\
\hline & SP & GB & AP & $A B$ & s.e. & Significance \\
\hline $\mathrm{N}$ intake (g) & $436^{k}$ & $437^{k}$ & $486^{\mathrm{j}}$ & $493^{\mathrm{j}}$ & 9.1 & $* * *$ \\
\hline \multicolumn{7}{|l|}{$\mathrm{N}$ output $(\mathrm{g})$} \\
\hline Faeces & $146^{\mathrm{j}}$ & $134^{\mathrm{jk}}$ & $140^{\mathrm{jk}}$ & $131^{\mathrm{k}}$ & 4.2 & $* *$ \\
\hline Urine & $95^{\mathrm{k}}$ & $103^{k}$ & $143^{j}$ & $149^{j}$ & 5.1 & $* * *$ \\
\hline Milk & $141^{\mathrm{k}}$ & $149^{j}$ & $141^{\mathrm{k}}$ & $154^{\mathrm{j}}$ & 6.2 & * \\
\hline Balance & 52 & 53 & 56 & 58 & 7.5 & \\
\hline Plasma urea (mmol/l) & $3.96^{\mathrm{k}}$ & $4.85^{\mathrm{j}}$ & $4.64^{\mathrm{j}}$ & $5.16^{\mathrm{j}}$ & 0.23 & $* *$ \\
\hline \multicolumn{7}{|l|}{$\mathrm{N}$ output ( $\%$ of intake) } \\
\hline Faeces & $33.6^{\mathrm{j}}$ & $30.6^{\mathrm{k}}$ & $28.8^{\mathrm{kl}}$ & $26.6^{1}$ & 0.94 & $* *$ \\
\hline Urine & $21.7^{\mathrm{k}}$ & $23.8^{k}$ & $29.4^{j}$ & $30.4^{j}$ & 1.33 & $* * *$ \\
\hline Milk & $32.4^{k}$ & $34.0^{\mathrm{j}}$ & $29.0^{1}$ & $31.1^{\mathrm{k}}$ & 1.20 & $* * *$ \\
\hline Balance $^{\ddagger}$ & 12.0 & 11.8 & 11.4 & 11.6 & 1.53 & \\
\hline$N A B^{\S}(\%$ of $N)$ & 6.30 & 6.32 & 6.07 & 6.54 & 0.23 & \\
\hline
\end{tabular}

${ }_{\mathrm{j}, \mathrm{k}, \mathrm{l}}$ Means within the same row and lactation stage with different superscripts differ $(P<0.05)$.

${ }^{\dagger} \mathrm{SP}=$ starch infused in abomasum; $\mathrm{GB}=$ glucose infused in blood; $\mathrm{AP}=$ amino acids infused in abomasum; $\mathrm{AB}=$ amino acids infused in blood.

${ }^{\ddagger}$ Calculated as: balance $=$ intake -milk-faeces-urine.

${ }^{\S}$ Nucleic acid bases.

milk, urine and faeces was similar for all treatments with an average of $88.3 \%$. No difference $(P>0.10)$ between treatments was found in faecal NAB excretion, which indicates similar microbial hind-gut fermentation.

\section{Plasma metabolites}

Plasma metabolites, hormones and extraction rates of plasma metabolites are presented in Tables 7, 8 and 9. Plasma glucose and extraction rates of glucose in the mammary gland were not affected $(P>0.1)$ by treatments (Table 7). Infusion of glucose into the blood by $365 \mathrm{~g}$ daily did not increase $(P>0.05)$ plasma glucose or insulin concentrations above that of the other treatments, although glucose concentration by the $\mathrm{GB}$ tended $(P<0.1)$ to be higher than the $S P$ and $A B$ treatments. Higher $(P<0.05)$ arterial NEFA concentration was observed in the $A B$ treatment, and the extraction rate of NEFA was positive for this treatment, but negative for the other treatments. Plasma glucagon concentration was lower $(P<0.05)$ for GB infusion and IGF-1 was higher $(P<0.05)$ by intravenous infusions (both $G B$ and $A B$ ) than with abomasal infusions (SP and AP). The plasma concentration of total AA (TAA) with $\mathrm{AP}$ infusion tended to be $(P<0.10)$ higher than with the other treatments (Table 8 ). Treatments $A P$ and $A B$ had higher $(P<0.05)$ plasma concentrations of EAA and branched-chain amino acids (BCAA) than the SP and GB

Table 7 Plasma metabolites and mammary extractions of metabolites by dairy cattle infused with carbohydrates or amino acids into the abomasum or blood in early lactation

\begin{tabular}{|c|c|c|c|c|c|c|}
\hline & \multicolumn{6}{|c|}{ Treatments $^{\dagger}$} \\
\hline & SP & GB & AP & $A B$ & s.e. & Significance \\
\hline \multicolumn{7}{|l|}{ Glucose (mmol/l) } \\
\hline Arterial & 3.28 & 3.42 & 3.37 & 3.28 & 0.074 & \\
\hline Extraction (\%) & 22.9 & 24.6 & 26.5 & 26.2 & 2.25 & \\
\hline \multicolumn{7}{|l|}{$\mathrm{NEFA}^{\ddagger}(\mathrm{mmol} / \mathrm{l})$} \\
\hline Arterial & $0.185^{k}$ & $0.170^{k}$ & $0.190^{k}$ & $0.222^{j}$ & 0.013 & ** \\
\hline Extraction (\%) & $-2.9^{j}$ & $-11.8^{k}$ & $-5.0^{\mathrm{jk}}$ & $2.5^{\mathrm{j}}$ & 3.90 & ** \\
\hline \multicolumn{7}{|l|}{ Hormones } \\
\hline Insulin (pmol/l) & 71.1 & 89.8 & 77.1 & 75.5 & 11.4 & \\
\hline Glucagon (ng/ml) & $56.3^{j}$ & $48.4^{k}$ & $56.1^{\mathrm{j}}$ & $60.7^{j}$ & 3.52 & $* *$ \\
\hline IGF-1 (ng/ml) & $63.6^{1}$ & $93.0^{j}$ & $71.8^{k}$ & $89.2^{\mathrm{j}}$ & 9.67 & $* * *$ \\
\hline $\mathrm{BGH}(\mathrm{ng} / \mathrm{ml})$ & 2.25 & 1.99 & 2.31 & 2.08 & 0.53 & \\
\hline
\end{tabular}

$j, k, l$ Means within the same row and lactation stage with different superscripts differ $(P<0.05)$.

${ }^{\dagger} \mathrm{SP}=$ starch infused in abomasum; $\mathrm{GB}=$ glucose infused in blood; $\mathrm{AP}=$ amino acids infused in abomasum; $\mathrm{AB}=$ amino acids infused in blood.

${ }^{\ddagger}$ Non esterified fatty acids. 
Schei, Danfær, Boman and Volden

Table 8 Mean arterial plasma amino acid concentrations ( $\mu \mathrm{mol} / \mathrm{l})$ by dairy cattle infused with carbohydrates or amino acids into the abomasum or blood in early lactation

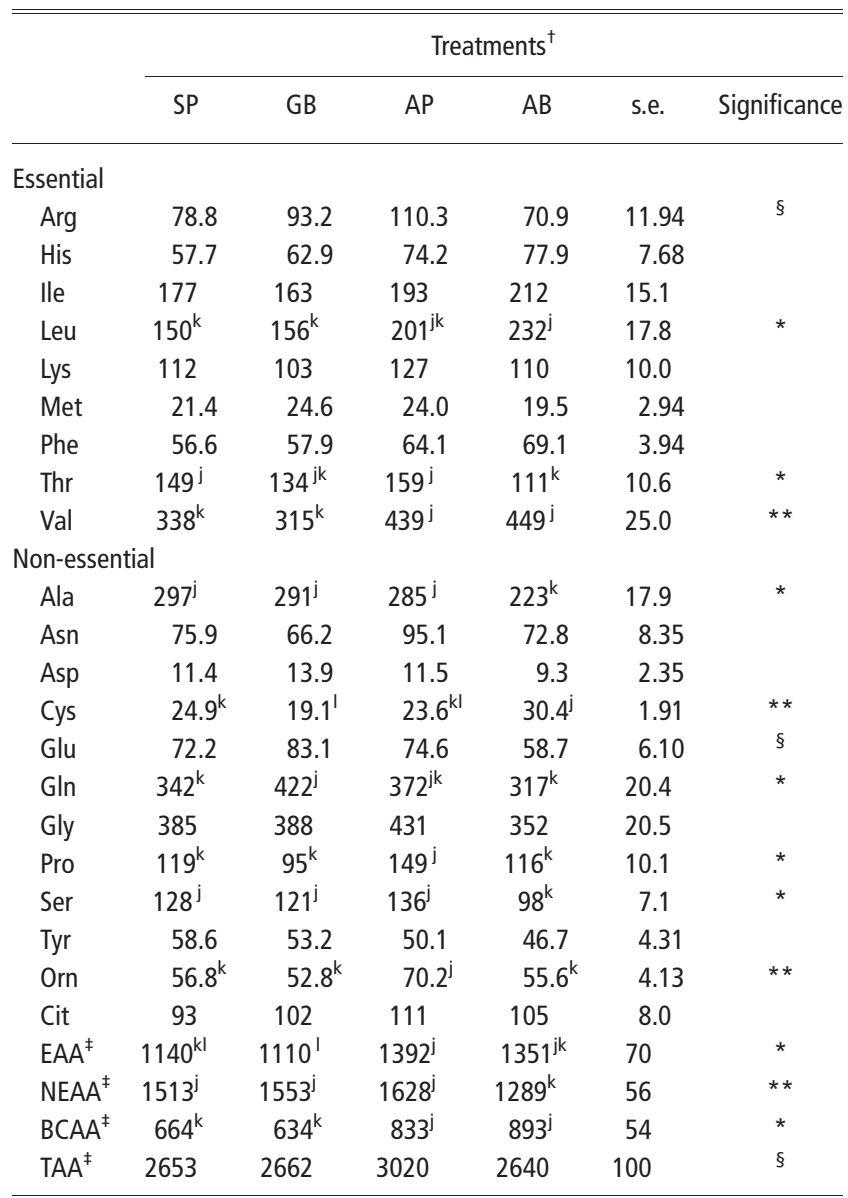

$\overline{\mathrm{j}, k, \mathrm{l}}$ Means within the same row and lactation stage with different superscripts differ $(P<0.05)$.

${ }^{\dagger} \mathrm{SP}=$ starch infused in abomasum; $\mathrm{GB}=$ glucose infused in blood; $\mathrm{AP}=$ amino acids infused in abomasum; $A B=$ amino acids infused in blood.

${ }^{\ddagger}$ EAA = essential AA (Arg, His, lle, Leu, Lys, Met, Phe, Thr, and Val); NEAA $=$ non-essential AA (Ala, Asn, Asp, Cys, Gln, Glu, Gly, Pro, Ser, and Tyr); $\mathrm{BCAA}=$ branched-chain AA (lle, Leu, and Val); TAA = EAA + NEAA.

${ }^{\S}$ Approaching significance $(P<0.10)$.

infusions, and the concentration of non-essential AA (NEAA) was lower $(P<0.05)$ for $A B$ infusion than with the other treatments. Of the EAA, Leu was higher on the $A B$ treatment whereas Val was higher by both $A P$ and $A B$ treatments than by the $S P$ and $G B$ treatments. The $A B$ infusion had lower plasma Thr $(P<0.05)$ and $\operatorname{Arg}(P<0.10)$ concentrations than the AP treatment. Of the NEAA, plasma concentrations of Ala and Ser were lower $(P<0.05)$ and Cys was higher $(P<0.05)$ for $A B$ infusion than by the other treatments. Moreover, the AP treatment had lower $(P<0.05)$ Pro and Orn, whereas Gln concentration was higher $(P<0.05)$ for $\mathrm{GB}$ infusion. The extraction rates differed $(P<0.05)$ between treatments in NEAA and tended to $(P<0.10)$ differ in TAA and EAA concentrations (Table 9). Highest extraction rate was found on the GB treatment and lowest on the $A B$ treatment. The extraction rate of EAA for the GB infusion was 49,42 and $84 \%$ higher than for the $S P, A P$ and $A B$ infusions, respectively.
Table 9 Mean extraction rate (\%) of plasma amino acid by the mammary gland by dairy cattle infused with carbohydrates or amino acids into the abomasum or blood in early lactation

\begin{tabular}{|c|c|c|c|c|c|c|}
\hline & \multicolumn{6}{|c|}{ Treatments $^{\dagger}$} \\
\hline & SP & GB & AP & $A B$ & s.e. & Significance \\
\hline \multicolumn{7}{|l|}{ Essential } \\
\hline $\operatorname{Arg}$ & 6.1 & 67.4 & 54.4 & 40.5 & 16.5 & $\S$ \\
\hline His & 46.6 & 52.7 & 25.9 & 35.2 & 6.66 & $\S$ \\
\hline Ile & 24.3 & 38.8 & 21.1 & 18.4 & 7.65 & \\
\hline Leu & 34.5 & 55.2 & 40.5 & 32.4 & 9.42 & \\
\hline Lys & 44.0 & 55.4 & 41.5 & 43.2 & 7.98 & \\
\hline Met & 30.4 & 68.0 & 32.1 & 54.7 & 18.1 & \\
\hline Phe & $38.8^{\mathrm{jk}}$ & $53.8^{\mathrm{j}}$ & $44.3^{\mathrm{jk}}$ & $28.8^{\mathrm{k}}$ & 5.28 & * \\
\hline Thr & 24.1 & 25.4 & 23.2 & 10.4 & 7.88 & \\
\hline Val & 20.3 & 22.4 & 15.5 & 8.8 & 4.92 & \\
\hline \multicolumn{7}{|c|}{ Non-essential } \\
\hline Ala & $9.2^{\mathrm{j}}$ & $13.4^{\mathrm{j}}$ & $1.6^{\mathrm{jk}}$ & $-6.4^{k}$ & 4.39 & * \\
\hline Asn & 31.0 & 15.0 & 15.4 & 6.7 & 8.34 & \\
\hline Asp & 42.8 & 19.0 & 22.4 & 11.8 & 12.2 & \\
\hline Cys & -7.8 & -32.9 & -12.2 & 4.3 & 16.9 & \\
\hline Glu & 65.8 & 71.5 & 69.7 & 67.2 & 5.56 & \\
\hline Gln & $25.6^{\mathrm{jk}}$ & $33.3^{\mathrm{j}}$ & $23.3^{\mathrm{jk}}$ & $14.3^{\mathrm{k}}$ & 3.98 & * \\
\hline Gly & 0.5 & 4.6 & 1.2 & -3.4 & 3.39 & \\
\hline Pro & -4.2 & -10.0 & 0.6 & 1.5 & 9.10 & \\
\hline Ser & 13.7 & 20.5 & 15.8 & 1.5 & 8.29 & \\
\hline Tyr & 42.3 & 37.6 & 53.2 & 41.6 & 8.01 & \\
\hline Orn & 43.3 & 52.0 & 44.9 & 43.4 & 5.31 & \\
\hline Cit & 5.3 & -6.6 & -3.7 & -2.4 & 9.34 & \\
\hline $\mathrm{EAA}^{\ddagger}$ & 27.9 & 41.5 & 29.2 & 22.5 & 5.27 & $\S$ \\
\hline $\operatorname{NEAA}^{\ddagger}$ & $15.8^{\mathrm{j}}$ & $19.7^{\mathrm{j}}$ & $14.5^{\mathrm{jk}}$ & $5.3^{k}$ & 3.22 & * \\
\hline $\mathrm{BCAA}^{\ddagger}$ & 25.5 & 35.3 & 22.4 & 16.4 & 6.24 & \\
\hline $\mathrm{TAA}^{\ddagger}$ & 21.5 & 28.9 & 21.4 & 14.0 & 3.91 & $\S$ \\
\hline
\end{tabular}

$\mathrm{j}, \mathrm{k}, \mathrm{l}$ Means within the same row and lactation stage with different superscripts differ $(P<0.05)$.

${ }^{\dagger} \mathrm{SP}=$ starch infused in abomasum; $\mathrm{GB}=$ glucose infused in blood; $\mathrm{AP}=$ amino acids infused in abomasum; $A B=$ amino acids infused in blood.

${ }^{\ddagger} \mathrm{EAA}=$ essential AA (Arg, His, Ile, Leu, Lys, Met, Phe, Thr, and Val); NEAA $=$ non-essential AA (Ala, Asn, Asp, Cys, Gln, Glu, Gly, Pro, Ser, and Tyr); $\mathrm{BCAA}=$ branched-chain AA (lle, Leu, and Val); TAA $=$ EAA + NEAA.

${ }^{\S}$ Approaching significance $(P<0.10)$.

\section{Discussion}

Planning of this experiment was done on the basis of abomasal nutrient flow and what can be achieved in practical diets. Hydrolysed wheat starch was chosen because it has a high intestinal digestibility, whereas the profile of the AA mixture was similar to what has been observed with grass silage-based diets. Choosing an AA profile other than casein that is more realistic to a practical feeding situation is important (Chamberlain and Yeo, 2003). DePeters and Cant (1992) and Schei et al. (2005) suggested that milk responses to additional nutrient supply depend on animal energy and nutrient balances. The production experiment of Schei et al. (2005) showed that increased metabolisable protein supply, when cows were in negative energy balance, increased milk protein production. However, it was not clear if the positive response was explained by solely an increased AA supply or a combination with increased 
glucose supply from increased gluconeogenesis. Therefore, the present experiment was designed to compare increased AA and glucose supplementation to cows in negative energy balance. The infusion periods lasted for 6 days and thus the duration should be suitable for achieving milk production responses since infusion responses largely occur within 1 to 3 days (Metcalf et al., 1996; Reynolds et al., 1994). Moreover, Knowlton et al. (1998) showed by summarising literature data that short-term $(<1$ week) infusion of glucose increased milk yield, whereas longer infusion indicated no prolonged responses. Using periods of 14 days, of which the first 7 days were with no infusion and the next 3 days were adapting to the infused nutrients before the start of treatment measurement, was sufficient to avoid possible carry-over effects from previous treatment. The restriction of the order of the treatments; avoiding two subsequent intravenous infusions, were done across substrates so there should be no systematic order of the substrates. Several studies have demonstrated a positive effect on milk production of infusing nutrients into the gastrointestinal tract or blood (Metcalf et al., 1996; Hurtaud et al., 2000; Reynolds et al., 2001; Aikman et al., 2002). However, limited data are available comparing both post-ruminal and intravenous AA and glucose supplementation in the same experiment and animals.

\section{Comparison of infusion sites within substrate type}

Changing infusion site from abomasal (SP and $A P$ ) to intravenous administration ( $G B$ and $A B$ ) gave higher daily milk yield $(1.4 \mathrm{~kg})$, milk protein yield $(69 \mathrm{~g})$ and protein content $(1.1 \mathrm{~g} / \mathrm{kg})$. These results indicate that increased supply of glucose and AA in the blood increased the nutrient supply to the mammary gland and that the supply of glucose and AA limited milk production. Therefore, our results suggest that starch and AA supplied via the abomasum did not reach the mammary gland although it clearly affected intermediary metabolism shown by differences in plasma urea concentrations, urinary $\mathrm{N}$ excretion and plasma $\mathrm{AA}$ concentrations.

Abomasal starch versus intravenous glucose infusions. No problem with soft faeces and diarrhoea were observed during starch infusions, and the dosage used here was lower than in other post-ruminal glucose or starch infusion studies (Hurtaud et al., 1998 and 2000; Reynolds et al., 2001). In a typical Norwegian dairy cow diet, which mainly consists of grass silage and a barley/oats based concentrate mixture when cows are fed 14 to $18 \mathrm{~kg} \mathrm{DM}$, abomasal infusion of 257 to $376 \mathrm{~g}$ of starch will increase the post-ruminal supply by approximately $100 \%$ (Volden, 1999). The total tract digestibility of starch was close to $100 \%$, but despite small amounts of starch infused it can not be excluded that the small intestinal digestibility was somewhat lower. However, no indication of higher microbial activity, measured as NAB excretion, was observed. This does not totally exclude faecal microbial growth differences between treatments since NAB measured in faeces could also be remnants of ruminal synthesis. But since cows were fed the same amount of feed, differences in ruminal microbial protein synthesis among infusion treatments is not expected. Starch has to undergo enzymatic activity for hydrolysis which also requires energy for enzyme synthesis and export to the lumen, and this might have reduced the availability of $A A$ and energy compared with glucose infused into blood. The $\mathrm{SP}$ infusion resulted in lower apparent digestibility of $\mathrm{CP}$ than did GB infusion. In addition to hind gut fermentation this difference could also be explained by a higher loss of endogenous protein due to increased intestinal digesta flow with abomasal infusion. Thomsen (1979) reviewed data on true protein digestibility and excretion of metabolic faecal nitrogen (MFN) in ruminants. The reported values of 84 to $96 \%$ true digestibility and 4.3 to $7.2 \mathrm{~g}$ MFN per kg DMl. Raggio et al. (2004) measured $\mathrm{N}$ balances in cows fed increasing amounts of dietary protein, and from their data the excretion of MFN can be estimated to 7.3 to $7.8 \mathrm{~g} / \mathrm{kg} \mathrm{DMI}$ assuming that $90 \%$ of dietary protein is truly digested at the faecal level. Using this assumption for the present study, the loss of MFN with starch infusion is calculated to $6.0 \mathrm{~g} / \mathrm{kg}$ DMI. The corresponding figure with intravenous glucose infusion is $5.2 \mathrm{~g} / \mathrm{kg}$ DMI. Shifting $\mathrm{N}$ excretion from urine to faeces would not decrease $A A$ availability per se, whereas an increased endogenous protein loss would. The higher AA availability through glucose blood infusion gave higher milk protein yield and protein concentration. However, the slightly higher feed intake on GB treatment would also contribute to a numerical higher milk yield. Higher AA availability on blood infusion numerically tended to increase urinary $\mathrm{N}$ loss and increased plasma urea level. The intention of infusing $\mathrm{CHO}$ substrate was to increase the glucogenic status and spare AA for use as glucose or energy substrates and thereby increase the availability of AA for protein synthesis in the mammary gland. Moreover, this will increase the arterial concentrations of glucogenic AA (Lemosquet et al., 2004). Substrates infused into the abomasum have to undergo digestion and absorption and pass the portal-drained viscera (PDV) and the liver before entering the peripheral blood. These processes may reduce the amount available for milk protein synthesis compared with intravenous infusion since these organs have high energy requirements (Reynolds, 2002). No differences were found in plasma EAA, NEAA, BCAA and TAA between SP and $G B$ infusions. Decreased plasma $B C A A$ and $E A A$ concentrations have been found in some trials with glucose infusion (Kim et al., 2001; Huhtanen et al., 2002) but not always (Kim et al., 2000; Rulquin et al., 2004). The variable effect is probably related to the response in milk protein yield. Limiting AA for milk protein synthesis can be identified when the plasma concentration is low and the mammary extraction rate is high (Guinard and Rulquin, 1994). In the SP treatment, extraction rates were generally low and it was highest for His. However, the relatively high arterial plasma His concentration indicates 
that His did not limit milk protein synthesis on the SP treatment. The extraction rate of His was rather high on the GB treatment, but still lower than the average value of $59 \%$ as found when His has been identified as the first limiting AA (Vanhatalo et al., 1999). The higher plasma Gln concentration for GB infusion suggests a sparing effect of this $A A$ from gluconeogenesis.

Abomasal v. intravenous AA infusions. Compared with the dietary metabolisable protein intake (the basal diet), abomasal infusion of $400 \mathrm{~g} \mathrm{AA}$ increased the metabolisable AA supply by more than $20 \%$, which has been shown to increase daily milk yield by $2.8 \mathrm{~kg}$ and milk protein production by $104 \mathrm{~g}$ in early lactating cows on low energy supply (Schei et al., 2005). Volden (1999) observed a 1.8$\mathrm{kg}$ increase in milk yield with $190 \mathrm{~g}$ increased duodenal AA supply in early lactating cows. In the present experiment, abomasal AA infusion resulted in a lower milk protein response than intravenous infusion. The abomasal infused AA have been absorbed, as shown by higher urinary $\mathrm{N}$ excretion, plasma urea and AA values, but it has not been used for milk protein synthesis. Our results indicate that abomasal infusions have increased the total protein loss and thus affected the AA supply for milk protein production. The faecal $\mathrm{N}$ loss was lower for blood infusion, but the apparent digestibility (calculated on basis of enteric protein intake) tended to be higher for abomasal infusion due to a higher protein intake. Assuming again a $90 \%$ true digestibility of enteric protein and amino acids, the loss of MFN with the AP treatment can be estimated as $5.4 \mathrm{~g} / \mathrm{kg}$ DMI. Thus, the MFN with abomasal AA infusion seems to be somewhat higher than with intravenous infusion $(5.0 \mathrm{~g} / \mathrm{kg} \mathrm{DMI})$. The higher $\mathrm{AA}$ availability (digested + infused) with blood infusion gave a higher milk protein yield, and also a higher lactose and milk yield, probably due to increased gluconeogenesis from $A A$. However, a numerical higher feed intake with the $A B$ treatment would also contribute to the higher milk yield.

The lower milk protein response in the AP treatment than the $A B$ treatment could also have been due to an interaction between $A A$ used in the small intestine and the infused $A A$ profile. The AA reaching the duodenum in a common grass silage-based diet can be limiting in specific AA. Infusion of individual AA, as His (Vanhatalo et al., 1999), Met (Pisulewski et al., 1996; Robinson et al., 2000) and Lys (Robinson et al., 2000) has increased the milk protein production, which indicates that these AA have been limiting milk protein synthesis. Compared with in His limiting diets (Thivierge et al., 2002), the present plasma His concentrations were high, and combined with low extraction rates, this suggests that His was not limiting on the AP or $A B$ treatments. Using National Research Council (2001) to calculate individual AA supply (including infused AA and assuming 100\% intestinal digestibility) indicate that neither Lys nor Met were limiting AA in the present study. This corresponds well to the high plasma concentrations observed for Lys. Hovewer, Met concentrations were clearly lower than what have been observed in high-yielding cows with possible Met limitation (Pisulewski et al., 1996).

When infusing into the blood the AA availability for intermediary metabolism is $100 \%$ while infusing into the gut it can be limited by digestion and absorption. The abomasal infusions have to cross the splanchnic tissues and are first modified by the liver (Reynolds et al., 1994) before it goes further to the mammary gland or other tissues. Thus, abomasal infusion will probably reduce the $A A$ available for milk production compared with intravenous infusions. It has been shown that there is a high rate of energy and protein turnover in the lumen wall and the PDV (Cant et al., 1996; Reynolds, 2002) and that there is a substantial metabolism of EAA during absorption by intestinal enterocytes (MacRae et al., 1997). Elevated luminal nutrient supply has shown to influence activity which promotes tissue growth (Cant et al., 1996). This is also demonstrated by infusion of glucose into the jejunum of rats, which stimulated mucosal protein synthesis (Weber et al., 1989). Reynolds et al. (2004) found that changes in gastro-intestinal and liver mass during transition are apparently consequences of changes in DMI and nutrient supply and not initiated by lactation per se. They also found that the type of diet had little effect on visceral mass. The idea of giving intravenous infusions is to avoid the first-pass extraction by the splanchnic tissues. However, $80 \%$ of $\mathrm{AA}$ sequestered in the gut tissue arises from the arterial supply to the gut (Seal and Parker, 2000) and, therefore, the gut tissue competes with the mammary gland for absorbed nutrients. This could partly explain the low recovery in milk protein also observed by intravenous infusions (Aikman et al., 2002) but it should indicate only a small reduction of response to abomasal infusion compared with intravenous infusion, which was not observed in the present study.

The loss of individual AA during absorption accounts for 36 to $100 \%$ (Tagari and Bergman, 1978). The highest consumption is found for Glu and Asp, which relates to their preferential use as energy substrates in intestinal tissues (Reynolds et al., 1994). However, the net flux of many AA is perhaps affected more by their uptake in the PDV from the blood (Reynolds, 2002). The relative rates of AA metabolism in PDV vary with requirements, nutrient supply (Reynolds, 2002) and physiological status, but the effect on milk protein production is not clear (Thivierge et al., 2002; Aikman et al., 2002). In our study, abomasal AA infusion resulted in higher plasma NEAA concentrations, and tended to be higher in TAA concentration, than did intravenous infusion, but the EAA and BCAA concentrations were unaffected. These results are in contrast to those of Thivierge et al. (2002), who used a similar AA mixture. They found that jugular infusion tended to increase EAA and BCAA plasma concentrations compared with abomasal infusion in cows 84 days in milk, but no differences were found in concentrations of NEAA. In their study, the basal protein level was low, but the energy balance of the cows was positive. This may suggest a higher supply of energy-yielding substrates than in the present study, which could result 
in a different fate of the infused $A A$. Our results indicate that there was a higher use of $A A$ for glucose production leading to a higher milk lactose yield on the $A B$ treatment than on the AP treatment. This agrees with the lower plasma concentrations of Ala, which is perhaps the most important glucogenic AA (Reynolds et al., 1994).

Reduced NEAA in plasma was also found in an earlier trial with abomasal casein infusion on a grass silagebased diet in which glucose was assumed to be a limiting factor (Miettinen and Huhtanen, 1997). In spite of the high content of Gln and Glu in the AA mixture infused, plasma concentrations of these AA did not increase compared with the SP and GB treatments. Gln and Glu did not differ between $A P$ and $A B$ infusion, which suggest a high use of these AA regardless of infusion site. As mentioned above, a high rate of Glu disappearance during intestinal absorption means that Glu and Gln from intravenous infusion have a different fate. These two $A A$ are involved in a large number of metabolic activities in the body, and their utilisation as energy sources have been demonstrated by reduced plasma concentrations during energy deficiencies (Meijer et al., 1995). Glu and Gln are also important precursors for glucose synthesis (Black et al., 1990) and when given intravenously, they could have contributed to the higher milk lactose yield. Danfær et al. (1995) reported from the literature a wide range of estimates (2 to $40 \%$ ) of the proportion of glucose derived from $A A$, and they found in their own study with lactating goats that portally infused AA could contribute to $36 \%$ of the hepatic glucose production. They concluded that the contribution of AA to glucose synthesis was regulated to a great extent by the availability of substrates. Gln has also been suggested to be a potential limiting $A A$ for milk protein synthesis in high yielding dairy cows, and the mammary extraction rate may be close to $100 \%$ (Meijer et al., 1995). Insufficient supply of Gln to the mammary gland will cost carbon skeletons derived primarily from glucose, and when milk protein synthesis is stimulated by infusion of protein, the plasma NEAA concentration will decrease (Meijer et al., 1995). However, the current understanding of the major role of Gln in the nutrient partitioning that occurs during lactation is not clear (Lobley et al., 2001).

Higher plasma NEAA on the AP than the $A B$ infusion was related to higher concentrations of Ala, Pro and Ser, and the low extraction ratios of these AA suggest an excessive supply from infusion in relation to the requirement on the AP treatment. Pro and Ser are also known to be glucogenic, although not to the same extent as Glu, Gln, Ala, Asp (Black et al., 1990). Higher plasma NEAA concentration for $A P$, and similar plasma urea and urinary $N$ excretion as for $A B$ infusion means that these $A A$ have been utilised anabolically in other peripheral tissues than the mammary gland. Higher endogenous protein excretion might have occurred on the abomasal infusions, and this would suggest a higher protein turnover and $A A$ requirement at the intestinal level.
Comparison of substrate type within infusion site

When comparing $\mathrm{CHO}$ and $\mathrm{AA}$ infusions within infusion site no differences in milk production were found, except for milk lactose concentration. Plasma urea, urinary $\mathrm{N}$ excretion and $\mathrm{N}$ balance were however affected by substrate type.

Abomasal starch versus $A A$ infusions. The apparent protein digestibility was lower on SP infusion than on AP infusion probably because the infused $A A$ had higher intestinal digestibility than $A A$ of dietary and microbial protein origin. The higher $A A$ availability on the $A P$ treatment increased plasma EAA and BCAA but it also resulted in increased urinary $\mathrm{N}$ excretion and plasma urea concentration. The lack of difference in milk responses between the two treatments does not support our hypothesis that post-ruminal AA supply to cows in negative energy balance would increase the EAA delivery to the mammary gland and thus improve milk protein synthesis compared with starch supply. The starch infusion did not affect milk fat concentration which is in line with earlier studies, when small amounts of glucose were infused (Kim et al., 2000; Vanhatalo et al., 2003a).

It has been shown by Volden (1999) that a diet consisting of grass silage and barley/oat based concentrate gives a low intestinal starch supply, which in turn could limit the glucose supply to the cows (Huhtanen et al., 2002). Increased ruminal escape of starch can improve $\mathrm{N}$ utilisation in PDV and liver, because the unfermented starch may directly supply glucose to PDV and spare use of glucogenic AA in the liver (Meijer et al., 1997). However, post-ruminal infusions of starch or glucose have shown minor effects on plasma AA (Vanhatalo et al., 2003b; Rulquin et al., 2004) maybe because energy and/or protein have been supplied close to or above requirements. Infusion of an AA mixture will provide both NEAA and EAA, and if NEAA are preferred as fuel in the gastro-intestinal tract and liver (Reynolds et al., 1994), the supply of EAA to the mammary gland might be improved. This was hypothesised in our study and we therefore expected increased milk protein content as a response to an improved EAA supply (Metcalf et al., 1996). However, this did not happen. Plasma concentrations of EAA and BCAA were higher on the AP than on the SP treatment. Although not always significant, numerically higher concentrations of many of the individual $A A$ were observed with the AP infusion than the SP infusion, but only minor effects were found on mammary extraction rates. The higher plasma concentration of EAA and BCAA in AP than in SP did not result in increased milk protein synthesis as found in other trials (Reynolds, 2002; Vanhatalo et al., 2003a). Higher plasma concentrations of Arg and Orn indicate a higher AA deamination on the AP treatment as supported by a higher plasma urea concentration and an increased urinary $\mathrm{N}$ excretion. The plasma concentration of Gln was not increased by abomasal AA infusion compared with starch infusion, which reflect a high rate of utilisation in the PDV during absorption as discussed above. It has been 
shown that glucose and GIn are equally important as energy substrates in mucosal cells of rat small intestine (Fleming et al., 1997) but in vitro studies have shown that Gln is not as important as glucose as energy source for enterocytes of lactating cows (Okine et al., 1995).

Intravenous glucose $v$. $A A$ infusions. The higher $A A$ availability in the AA infusion increased urinary $\mathrm{N}$ excretion compared with glucose infusion. Numerical lower energy balance in the $A B$ than in the $G B$ infusion is a result of a higher mobilisation of $A A$ in the $A B$ treatment or a higher partition of nutrients towards the body in the $G B$ treatment. The positive effect of infusing glucose or $A A$ into the blood on milk yield indicates that the cow's glycogenic status, as well as the AA supplied limited milk protein production. These results are in line with observations found by Vanhatalo et al. (2003a) where abomasal infusion of $300 \mathrm{~g}$ of casein or glucose to cows in early lactation increased milk and protein yield in similar amount, suggesting that glucose alone increased milk protein production by sparing AA from hepatic utilisation and that these cows suffered from both limited $A A$ and glucose supply. However, in the present study, the low supply of metabolisable protein from the basal diet and reduced infusion amounts in the $A P$ and $A B$ infusions compared with SP and GB infusion, combined with similar responses may suggest that $A A$ were more limited for milk protein synthesis than did glucose. Most comparisons of $\mathrm{CHO}$ and $\mathrm{AA}$ infusions have been done using casein or profile of casein as the AA substrate (Kim et al., 2000; Vanhatalo et al., 2003a and b). With the exception of Vanhatalo et al. (2003a), these trials showed a positive effect of casein compared with glucose, suggesting that AA were more limiting than glucose.

Hepatic metabolism of glucogenic AA into glucose synthesis is to a great extent regulated by the availability of substrates (Danfær et al., 1995). When glucose supply is limited, particularly in early lactation, the use of AA as glucose precursors may be high to prevent the shortfall of glucose (Danfær et al., 1995). The infusion of glucose could spare almost twice its own weight of glucogenic AA (Krebs, 1964). In our study, the type of intravenous substrate affected plasma concentration of BCAA, EAA and NEAA. The extraction rate of EAA for GB infusion was high and for $A B$ infusion low compared with what has been reported by others (Vanhatalo et al., 2003a and b). Extraction rates of NEAA were lower than that of EAA and varied more between the individual $A A$, which agrees with results from Guinard and Rulquin (1994). The ratio between plasma EAA and NEAA concentration has been used to evaluate the adequacy of AA supply as this ratio should increase when the protein balance is improved (Bergen et al., 1973). On the GB treatment, this ratio was 0.71 and the corresponding value for the $A B$ treatment was 1.04 . According to this approach, the protein balance was improved for $A B$ infusion compared with $G B$ infusion. These ratios are lower than those observed by Thivierge et al. (2002) who compared abomasal and jugular infusions. But they are higher or close to corresponding values where glucose supply was considered as limiting (Miettinen and Huhtanen, 1997; Vanhatalo et al., 2003a).

Intravenous infusion of the AA mixture provided precursors both in terms of EAA for milk protein synthesis and NEAA for gluconeogenesis in the liver. The higher level of EAA and the lower level of NEAA in plasma observed on the $A B$ treatment are in agreement with results from abomasal casein infusion studies (Miettinen and Huhtanen, 1997; Vanhatalo et al., 2003b). Decreased plasma concentrations of Ala, Gln, Gly and Ser confirm the role of these particular AA as substrates for glucose synthesis (Black et al., 1990) and correspond well to the reduced NEAA concentrations found by Vanhatalo et al. (2003b). The results confirm the importance of NEAA as carbon sources for liver glucose synthesis, but their utilisation depends on an adequate and balanced supply of EAA (Reynolds, 2002).

\section{Conclusions}

This study demonstrate that, compared with post-ruminal starch and AA infusion, intravenous infusion of glucose or AA daily have a positive effect on protein yield and concentration to cows in negative energy balance. These findings suggest higher losses of MFN by abomasal infusions, and that the abomasally infused nutrients did not reach the mammary gland and thus resulted in lower milk production. Intravenous infusion of glucose did not increase plasma glucose or insulin concentrations above that of abomasal starch infusion. Compared with abomasal starch infusion, intravenous glucose infusion had minor effect on plasma AA. Abomasal AA infusion increased plasma NEAA concentration compared with intravenous AA infusion, but infusion site of $A A$ had no effect on EAA or $B C A A$. Although a higher milk protein synthesis was observed by intravenous AA infusion, the mammary extraction rate was not higher than by abomasal AA infusion. These results suggest that some of the AA infused in the abomasum have been used in the gastrointestinal tract and/or the liver. Lower plasma NEAA concentrations, in particular Ala, by intravenous AA infusion suggest a higher gluconeogenesis of these AA. Infusion of $A A$ increased plasma concentration of EAA and BCAA, but compared with blood glucose infusion, the mammary extraction rate tended to be lower. Our results suggest that when glucose was infused, AA limited a further milk protein synthesis, but when AA was infused, glucose or energy substrate might have been the limiting factor. Gastro-intestinal metabolism influences the nutrients available for milk synthesis and should therefore be taken into account when developing new feed evaluation systems for dairy cows.

\section{Acknowledgements}

The authors thank Dr L. T. Mydland for all help with blood sampling and preparation of solutions, Dr E. Prestløkken for 
help with blood sampling, Professor K. Hove for surgery on the cows and the staff at Department of Animal and Aquacultural Sciences for their animal care and execution of the practical work. This work was funded by the Norwegian Research Council (grant no. 153019/110) and TINE Dairies BA.

\section{References}

Aikman PC, Reynolds CK, Humphries DJ, Beever DE and MacRae JC 2002. Milk protein response to abomasal or mesenteric vein essential amino acid infusion in lactating dairy cows. Journal of Dairy Science 85, 1079-1084.

Association of Official Analytical Chemists 1980. Official methods of analysis, 13th edition. AOAC, Washington DC.

Bergen WG, Henneman HA and Magee WT 1973. Effect of dietary protein level and protein source on plasma and tissue free amino acids in growing sheep. Journal of Nutrition 103, 575-585.

Black AL, Anan RS, Bruss ML and Brown CA 1990. Partitioning of amino acids in lactating cows: oxidation to carbon dioxide. Journal of Nutrition 120, 700-710.

Boisen S and Verstegen MWA 2000. Developments in the measurement of the energy content of feeds and energy utilisation in animals. In Feed evaluation: principles and practice (ed. PJ Moughan and MWA Verstegen and MI Visser-Reyneveld), pp. 57-76. Wageningen Pers, Wageningen, The Netherlands.

Cant JP, McBride BW and Croom WJ Jr 1996. The regulation of intestinal metabolism and its impact on whole animal energetics. Journal of Animal Science 74, 2541-2553.

Chamberlain DG and Yeo J-M 2003. Effects of amino acids on milk production. In Amino acids in animal nutrition, second edition (ed. JPF D'Mello), pp. 367-387. CABI Publishing, 0xon, UK.

Danfær A, Tetens V and Agergaard N 1995. Rewiew and an experimental study on the physiological and quantitative aspects of gluconeogenesis in lactating ruminants. Comparative biochemistry and physiology 111B (2), 201-210.

DePeters EJ and Cant JP 1992. Nutritional factors influencing the nitrogen composition of bovine milk: a review. Journal of Dairy Science 75, 2043-2070.

Ekern A 1991. A new system of energy evaluation of feed for ruminants. Norsk landbruksforskning 5, 273-277.

Fleming SE, Zambell KL and Fitch MD 1997. Glucose and glutamine provides similar proportions of energy to mucosal cells of rat small intestine. American Journal of Physiology 273 (Gastrointestinal Liver Physiology 36) G968-G978.

Frystyk J, Dinesen B and Ørskov H 1995. Non-competitive time-resolved immunofluorometric assays for determination of human insulin-like growth factor I and II. Growth Reg 5, 169-176.

Guinard J and Rulquin H 1994. Effect of graded levels of duodenal infusions of casein on mammary uptake in lactating cows 2. Individual amino acids. Journal of Dairy Science 77, 3304-3315.

Huhtanen P, Vanhatalo A and Varvikko T 2002. Effects of abomasal infusions of histidine, glucose, and leucine on milk production and plasma metabolites of dairy cows fed grass silage diets. Journal of Dairy Science 85, 204-216.

Hurtaud C, Lemosquet S and Rulquin H 2000. Effect of graded duodenal infusions of glucose on yield and composition of milk from dairy cows 2 . Diets based on grass silage. Journal of Dairy Science 83, 2952-2962.

Hurtaud C, Rulquin H and Verite R 1998. Effects of graded duodenal infusions of glucose on yield and composition of milk from dairy cows 1. Diets based on corn silage. Journal of Dairy Science 81, 3239-3247.

Hurtaud C-H, Choung J-J and Chamberlain CG 2000. The effects of intravenous administration of amino acids and glucose on the milk production of dairy cows consuming diets based on grass silage. Grass and Forage Science 55, 173-180.

Kim C-H, Choung J-J and Chamberlain CG 2000. The effects of intravenous administration of amino acids and glucose on the milk production of dairy cows consuming diets based on grass silage. Grass and Forage Science 55, 173-180.

Kim C-H, Kim TG, Choung J-J and Chamberlain CG 2001. Effects of intravenous infusion of amino acids and glucose on the yield and concentration of milk protein in dairy cows. Journal of Dairy Research 68, 27-34.
Knowlton KF, Dawson TE, Glenn BP, Huntington GB and Erdman RA 1998. Glucose metabolism and milk yield of cows infused abomasally or ruminally with starch. Journal of Dairy Science 81, 3248-3258.

Krebs HA 1964. The metablic fate of amino acids. In Mammalian protein metabolism, volume 1 (ed. HA Munro and JB Allison), pp. 125-177. Academic Press, New York.

Lemosquet S, Rigout S, Bach A, Rulquin H and Blum JW 2004. Glucose metabolism in lactating cows in response to isoenergetic infusions of propionic acid or duodenal glucose. Journal of Dairy Science 87, 1767-1777.

Lobley GE, Hoskin SO and McNeil CJ 2001. Glutamine in animal science and production. Journal of Nutrition 131, 2525S-2531S.

Løvendahl P and Purup HM 2002. Technical note: time-resolved fluoro-immunometric assay for intact insulin in livestock species. Journal of Animal Science 80, 191-195.

Løvendahl P, Adamsen J, Lund R and Lind P 2003. Technical note: timeresolved immunofluorometric assay for growth hormone in ruminants. Journal of Animal Science 81, 1294-1299.

McCleary BV, Gibson TS, Solah V and Mugford DC 1994. Total starch measurements in cereal products interlaboratory evaluation of rapid enzymatic test procedure. Cereal Chemistry 71, 501-505.

MacRae JC, Bruce LA, Brown DS, Farningham DAH and Franklin M 1997. Absorption of amino acids from the intestine and their net flux across the mesenteric- and portal-drained-viscera of lambs. Journal of Animal Science 75, 3307-3314.

Madsen J, Hvelplund T, Weisbjerg MR, Bertilsson J, Olsson I, Spörndly R, Harstad OM, Volden $\mathrm{H}$, Tuori M, Varvikko T, Huhtanen P and Olafsson BL 1995. The AAT/PBV protein evaluation system for ruminants. Norwegian Journal of Agricultural Science (suppl. 19) 1-37.

Makkar HPS and Becker K 1999. Purine quantification in digesta from ruminants by spectophotometric and HPLC methods. British Journal of Nutrition 81, 107-112.

Meijer GAL, Bontempo V, Van Vuuren AM and Van der Meulen J 1997. Effect of starch on the bioavailability of glutamine and leucine in the dairy cow. Journal of Dairy Science 80, 2143-2148.

Meijer GAL, Van der Meulen J, Bakker JGM, Van der Koelen CJ and Van Vuuren AM 1995. Free amino acids in plasma and muscle of high yielding dairy cows in early lactation. Journal of Dairy Science 78, 1131-1141.

Metcalf JA, Crompton LA, Wray-Cahen D, Lomax MA, Sutton JD, Beever $D E$, MacRae JC, Bequette BJ, Backwell FRC and Lobley GE 1996. Responses in milk constituents to intravascular administration of two mixtures of amino acids to dairy cows. Journal of Dairy Science 79, 1425-1429.

Miettinen $\mathrm{HO}$ and Huhtanen PJ 1997. Effects of silage fermentation and post-ruminal casein supplementation in lactating dairy cows 2 . Energy metabolites and plasma amino acids. Journal of Science of Food and Agriculture 74, 459-468.

National Research Council 2001. Nutrient requirements of dairy cattle, seventh revised edition. National Academy Press, Washington DC.

Nocek JE and Tamminga S 1991. Site of digestion of starch in the gastrointestinal tract of dairy cows and its effect on milk yield and composition. Journal of Dairy Science 74, 3598-3629.

Okine EK, Glimm DR, Thompson JR and Kennelly JJ 1995. Influence of stage of lactation on glucose and glutamine metabolism in isolated enterocytes from dairy cattle. Metabolism 44, 325-331.

Ørskov ER, Reid GW and McDonald I 1981. Effects of protein degradability and food intake on milk yield and composition in cows in early lactation. British Journal of Nutrition 45, 547-555.

Pisulewski PM, Rulquin H, Peyraud JL and Verite R 1996. Lactational and systemic responses of dairy cows to postruminal infusions of increasing amounts of methionine. Journal of Dairy Science 79, 1781-1791.

Raggio G, Pacheco D, Berthiaume R, Lobley GE, Pellerin D, Allard G, Dubreuil $P$ and Lapierre H 2004. Effects of metabolizable protein on splanchnic flux of amino acids in lactating cows. Journal of Dairy Science 87, 3461-3472.

Reynolds CK 2002. Economics of visceral energy metabolism in ruminants: toll keeping or internal revenue service? Journal of Animal Science 80, (E suppl. 2), E74-E84.

Reynolds CK, Cammell SB, Humphries DJ, Beever DE, Sutton JD and Newbold JR 2001. Effect of postrumen starch infusion on milk production and energy metabolism in dairy cows. Journal of Dairy Science $84,2250-2259$. 
Reynolds CK, Dürst B, Lupoli B, Humphries DJ and Beever DE 2004. Visceral tissue mass and rumen volume in dairy cows during the transition from late gestation to early lactation. Journal of Dairy Science 87, 961-971.

Reynolds CK, Harmon DL and Cecava MJ 1994. Absorption and delivery of nutrients for milk protein synthesis by portal-drained viscera. Journal of Dairy Science 77, 2787-2808.

Robinson PH, Chalupa W, Sniffen CJ, Julien WE, Sato H, Fujieda T, Ueda T and Suzuki H 2000. Influence of abomasal infusion of high levels of lysine or methionine, or both, on ruminal fermentation, eating behavior, and performance of lactating dairy cows. Journal of Animal Science 78, 1067-1077.

Rulquin $\mathrm{H}$, Rigout $\mathrm{S}$, Lemosquet $\mathrm{S}$ and Bach A 2004. Infusion of glucose directs circulating amino acids to the mammary gland in well-fed cows. Journal of Dairy Science 87, 340-349.

Schei I, Volden H and Bævre L 2005. Effects of energy balance and metabolizable protein level on tissue mobilization and milk performance of dairy cows in early lactation. Livestock Production Science 95, 35-47.

Seal CJ and Parker DS 2000. Influence of gastrointestinal metabolism on substrate supply to the liver. In Ruminant physiology: digestion, metabolism, growth and reproduction (ed. PB Cronje), pp. 131-148. CABI Publishing, Oxon, UK.

Sjaunja LO, Bævre L, Junkkarinen L, Pedersen J and Setälä J 1990. A Nordic proposal for an energy corrected milk (ECM) formula paper presented at the 27th session of the International Committee for Breeding and Productivity of Milk Animals, Paris 2-6 July.

Statistical Analysis Systems Institute 1999. Software release 8.2. SAS Institute Inc., Cary, NC.

Tagari $\mathrm{H}$ and Bergman EN 1978. Intestinal disappearance and portal blood appearance of amino acids in sheep. Journal of Nutrition 108, 790-803.

Thivierge MC, Bernier JF, Dubreuil P and Lapierre H 2002. The effect of jugular or abomasal infusion of amino acids on milk yield in lactating cows fed a protein deficient diet. Reproduction Nutrition Development 42, 1-13.

Thomsen KV 1979. [Information on and calculation of digestible crude protein in cattle and sheep.] Meddelelse $\mathrm{Nr} 269$ fra Statens Husdyrbrugsforsøg, København.
Van Es AJH 1975. Feed evaluation for dairy cows. Livestock Production Science 2, 95-107.

Van Es AJH 1978. Feed evaluation for ruminants. 1. The systems in use from May 1977 onwards in The Netherlands. Livestock Production Science 5, 331-345.

Van Soest PJ, Robertson JB and Lewis BA 1991. Methods for dietary fibre, neutral detergent fibre and nonstarch polysaccharides in relation to animal nutrition. Journal of Dairy Science 74, 3583-3597.

Vanhatalo A, Huhtanen P, Toivonen V and Varvikko T 1999. Response of dairy cows fed grass silage diets to abomasal infusions of histidine alone or in combinations with methionine and lysine. Journal of Dairy Science 82, 2674-2685.

Vanhatalo A, Varvikko T and Huhtanen P 2003a. Effects of casein and glucose on responses of cows fed diets based on restrictively fermented grass silage. Journal of Dairy Science 86, 3260-3270.

Vanhatalo A, Varvikko T and Huhtanen P 2003b. Effects of various glucogenic sources on production and metabolic responses of dairy cows fed grass silage-based diets. Journal of Dairy Science 86, 3249-3259.

Volden H 1999. Effects of level of feeding and ruminally undegraded protein on ruminal bacterial protein synthesis, escape of dietary protein, intestinal amino acid profile, and performance of dairy cows. Journal of Animal Science 77, 1905-1918.

Volden $\mathrm{H}$ and Harstad OM 2002. Effects of duodenal amino acid and starch infusion on milk production and nitrogen balance in dairy cows. Journal of Animal Science 80, (suppl. 1) 321 (abstr.).

Volden H, Mydland LT and Harstad OM 1999. Chemical composition of protozoal and bacterial fractions isolated from ruminal contents of dairy cows fed diets differing in nitrogen supplementation. Acta Agriculturae Scandinavica Section A. Animal Science 49, 235-244.

Weber FL Jr, Fresard KM and Veach GL 1989. Stimulation of jejunal mucosal protein synthesis by luminal glucose: effects with luminal and vascular leucine in fed and fasted rats. Gastroenterology 96, 935-937. 